\title{
MINERAL RESOURCE POTENTIAL OF THE MUDDY MOUNTAINS WILDERNESS STUDY AREA, CLARK COUNTY, NEVADA
}

\author{
By \\ Robert G. Bohannon, U.S. Geological Survey, \\ and \\ Andrew M. Leszcykowski, Leon E. Esparza, and Clayton M. Rumsey \\ U.S. Bureau of Mines \\ 1982
}

STUDIES RELATED TO WILDERNESS

Bureau of Land Management Wilderness Study Areas

The Federal Land Policy and Management Act (Public Law 94-579, October 21, 1976) requires the U.S. Geological Survey and the U.S. Bureau of Mines to conduct mineral surveys on certain areas to determine their mineral resource potential. Results must be made available to the public and be submitted to the President and the Congress. This report presents the results of a mineral survey of the Muddy Mountains Wilderness Study Area, Clark County, Nevada.

\section{MINERAL RESOURCE POTENTIAL SUMMARY STATEMENT}

The Muddy Mountains Wilderness Study Area (WSA 050-0229), Clark County, Nevada, has a high potential for mineral deposits of calcium borates and lithium. The known and potential mineral deposits are concentrated in the east-central and south-central parts of the study area (see map). Zeolites (in particular clinoptilolite) are present in some tuff beds throughout much of the study area, and this resource potential is probably moderate to high. Stream-sediment sampling suggests that the Muddy Mountains area has little potential for mineral deposits of metals (other than lithium). Clay minerals are mined at one locality in the area (see map). Building stone and silica sand have moderate to low potential in some places. Oil and gas potential within the study area is low, but complete evaluation of its potential is not possible without drilling.

\section{INTRODUCTION}

The Muddy Mountains WSA comprises about 107,000 acres $(43,000$ hectares) in the highest and most inaccessible part of the Muddy Mountains about $23 \mathrm{mi}$ $(35 \mathrm{~km})$ east-northeast of Las Vegas in southeastern Nevada (fig. 1). Muddy Peak, which is $5,363 \mathrm{ft}(1,635$ $\mathrm{m}$ ) in altitude in the central part of the WSA, has a steep eastern face adjacent to the floor of White Basin, which is in the northeastern part of the WSA and is about $2,000 \mathrm{ft}(600 \mathrm{~m})$ lower than the peak. Bitter Ridge, an east- and northeast-trending hogback about 3,000 ft $(900 \mathrm{~m}) \mathrm{high}$, separates White Basin from Bitter Spring Valley in the southeastern part of the WSA. Rugged hills about 2,500-3,000 ft (750-900 $m$ ) high known as the Gale Hills compose the southwest corner of the WSA; the northwest corner is in the southern end of California Wash.

Between Frenchman Mountain and the northern part of the Black Mountains the southwestern border of the WSA follows a maintained dirt road that joins the paved Northshore Road (Highway 41A) at West End Wash (figs. 1 and 3). East of West End Wash the southern border of the WSA is coincident with the northern border of the Lake Mead National Recreation Area, and access to this part is from the Northshore Road which is south of the border. The northeast border of the WSA follows the Borax Road, a dirt road that extends diagonally through White Basin and Buffington Pockets. The west border of the WSA is not easily accessible.

\section{GEOLOGIC SETTING}

Sedimentary rocks of various types and ages are exposed in the Muddy Mountains WSA. Paleozoic rocks are mostly limestone and dolomite with lesser amounts of sandstone that were deposited in a shallow sea and adjacent continental river system that formed on the cratonic platform and outer cratonic platform or shelf margin. Mesozoic rocks are chiefly nonmarine clastic rocks that formed in tidal flat, floodplain, fluvial, swamp, and eolian environments. Mesozoic nearshore marine rocks also occur. Tertiary rocks were deposited in a complex system of basins that evolved during Miocene time as the Basin and Range structural province was forming. From oldest to youngest, these basins are the Rainbow Gardens, the Thumb, the Bitter Ridge-Lovell Wash, the White, and the Muddy Creek. The Rainbow Gardens basin existed between 20 and $16.5 \mathrm{~m} . \mathrm{y}$. ago and in it accumulated a thin sequence of lacustrine rocks of various lithologies. The Thumb basin, in which thick accumulations of fluvial, alluvial, and lacustrine clastic rocks were deposited, existed 
16.5-13.5 m.y. ago. The Bitter Ridge-Lovell Wash was the site of deposition of a thick section of lacustrine carbonate and volcaniclastic rocks about $13.5-12 \mathrm{~m} . \mathrm{y}$. ago. White Basin is a graben into which a thick accumulation of red alluvial and fluvial sandstone was shed 12-10 m.y. ago. The Muddy Creek is a Basin-andRange basin in which thick deposits of pink to brown siltstone and fine-grained sandstone accumulated about 10-5 m.y. ago. A variety of Quaternary surficial deposits cover large parts of the WSA, and these consist chiefly of unconsolidated to poorly consolidated sand and gravel.

The Muddy Mountain thrust fault, a Late Cretaceous to early Tertiary(?) structure of regional extent dominates the central and northern parts of the WSA. It and its overlying allochthon dip northwest in the northern part of the WSA. The thrust is probably present in the subsurface throughout the north and western part of the WSA beneath the Tertiary Horse Spring and Muddy Creek Formations and the young valley fill of California Wash. In the central part of the WSA, north of Muddy Peak, the thrust trends eastwest and dips south. Because the allochthonous rocks above the thrust dip homoclinally southward in that area, the thrust surface is assumed to maintain an even south dip in the subsurface throughout the Muddy Peak and northern Gale Hills areas. However, drillhole data in the southern Gale Hills and Bowl of Fire (Bohannon and Bachhuber, 1979) indicate that the Muddy Mountain thrust is not present in the subsurface in that area; possibly it has been eroded there. Most of the Mesozoic and Paleozoic rocks there are autochthonous.

Several middle Tertiary to Quaternary faults in and near the WSA exerted a strong control over Tertiary and Quaternary sedimentation patterns or have displaced Tertiary rocks or Quaternary alluvium (fig. 2). The Gale Hills fault, a complex, southdipping, normal fault system southwest of Muddy Peak, was the northeast margin of the Thumb basin 16.5-13.5 m.y. ago. Although no mineralization is known to have been controlled by the fault system itself, the faults controlled the deposition of tuff beds that are zeolitized. Similarly, the Muddy Peak fault, a large, east-dipping normal fault at the west boundary of White Basin, controlled the deposition of the red sandstone unit and the youngest beds of the Lovell Wash Member of the Horse Spring Formation. In the interior of White Basin, the Borax fault was active as a right-lateral fault during sedimentation of the red sandstone unit and the Lovell Wash Member. At the northwest corner of White Basin, the Borax fault changes trend and character, becoming a northtrending, east-dipping, basin-bounding normal fault. A similar change of trend and character occurs on the West Bowl of Fire fault in the southern part of the WSA; the fault changes from a low-angle, westdipping, north-northeast-trending normal fault near Bowl of Fire to a west-trending zone along which drag folds indicate a strong component of left slip. The Lovell fault is an east-dipping, north-northeasttrending normal fault that joins, and is probably similar to, the West Bowl of Fire fault. The East Bowl of Fire fault, another east-dipping, north-trending normal fault, is east of the Bowl of Fire and joins the West Bowl of Fire fault in the southeastern part of the
WSA. Although a fault continues on the northerly trend of the East and West Bowl of Fire faults beyond their junction, its displacement is minor. In the northwest part of the WSA the California Wash fault displaces Quaternary alluvium and represents the only recognized Quaternary faulting in the area.

\section{GEOCHEMISTRY}

The results of spectrographic and atomic-absorption analyses of 135 stream-sediment samples taken from within the WSA boundary (Bohannon and Vine, 1982) indicate no significant enrichment in metals, other than lithium. Arsenic, gold, bismuth, cadmium, antimony, tin, tungsten, zinc, and thorium were not detected in any of the samples by either analytic technique (Bohannon and Vine, 1982). Silver was detected, but in only two of the samples, and it was only slightly above the limits of detection. Chromium was slightly anomalous in one sample, molybdenum was slightly anomalous in 12 samples, strontium slightly anomalous in one, and zirconium slightly anomalous in one. The chromium anomaly might have originated in a nearby fault zone, although no obvious chrome mineralization is present in the zone. The molybdenum anomalies are only slightly above the limits of detection and probably do not indicate important undiscovered reserves. The strontium anomaly may be from a local occurrence of celestite within a gypsum bed. The source of the zirconium anomaly is not known. Iron, manganese, copper, nickel, and lead were all detected in the analyses, but the values are low and fall within narrow ranges; anomalies are not present.

\section{MINES AND PROSPECTS}

Numerous mineral claims are in or near the study area according to Clark County records. Most were staked for borate minerals in the 1920's and 1930's. The locations of 35 mines and prospects examined during the study are shown on figure 3 and described in table 1.

Known areas where borate minerals or clay associated with them have been mined or where potential for these minerals still exists are in White Basin, Lovell Wash, and Gale Hills. Other areas that contain possible resources, as determined by this investigation, are Gale Hills (zeolites and silica sand), Lovell Wash (zeolites and lithium), Bitter Spring Valley (zeolites), and White Basin (lithium).

Most of the mining activity for borate minerals has been at the Anniversary Mine in Lovell Wash and the American Borax Company Mine in White Basin. Both mines lie on or outside the WSA boundary. The Anniversary Mine has about $7,000 \mathrm{ft}(2,100 \mathrm{~m})$ of underground workings on five levels. The American Borax Mine workings, reported to be several hundred feet long, are inaccessible. Calcining mills (now removed) were on both properties during mining operations. The Anniversary Mine was active from 1922 to $1928 ; 200,000$ tons (180,000 metric tons) of 19-24 percent $\mathrm{B}_{2} \mathrm{O}_{3}$ ore were produced. Operations were discontinued because of competition from borate mines in California. American Borax Company was active from 1922 to 1924 , when operations ceased 
because litigation and high production costs forced closure. No record was found of grade or tonnage of ore produced at the American Borax Mine.

The Anniversary Mine is in the Bitter Ridge Limestone and Lovell Wash Members of the Horse Spring Formation, a sequence of tuff, limestone, siltstone, and claystone which makes up the north limb of an east-trending syncline. The syncline plunges to the east, and the north limb dips to the south $45^{\circ}$ $60^{\circ}$. The deposit is a layer of colemanite-bearing clays that ranges from 6 to $18 \mathrm{ft}(1.8$ to $5.5 \mathrm{~m})$ thick. The bed is bounded on the top by limestone that has stromatolitic eggshell structure and on the bottom by a thin layer of ulexite. The American Borax Mine is in a claystone, limestone, and tuff sequence of the Lovell Wash Member that dips northwest $24^{\circ}$. The mine workings followed a $2-$ to $5-\mathrm{ft}-(0.6$ to $1.5 \mathrm{~m})$ thick, colemanite-bearing, claystone unit.

The Vanderbilt Mine, owned by Western Talc Company, produces clay that is stockpiled at the mine and used as needed. Several thousand tons have been mined predominantly for use as a thixotropic agent in drilling mud. The clay, predominantly montmorillonite, is in a $2-\mathrm{ft}-(0.6 \mathrm{~m})$ thick bed within a limestone sequence in the Thumb Member of the Horse Spring Formation. The clay bed strikes N. $25^{\circ}$ W., dips $15^{\circ}-$ $20^{\circ}$ southwest, and is exposed in a recently dug pit for about $1,200 \mathrm{ft}(370 \mathrm{~m})$ along strike and $400 \mathrm{ft}(120 \mathrm{~m})$ downdip. Deposits of this type are formed in a geologic environment which is not common or generally large. Hence, it is unlikely that large undiscovered deposits exist.

Aztec Sandstone from the Colorock Quarry has been used as construction stone; it underlies parts of the study area. Because the quality is below that for sandstone regionally marketed, its use will probably be restricted to local consumption. Agate and opal found in the area have little commercial value as gemstones.

Silica sand is mined from the Cretaceous Baseline Sandstone $16 \mathrm{mi}(26 \mathrm{~km})$ north of the study area by Simplot Silica Company (Smith, 1959). Ottawa Silica Company has explored for silica sand in the Baseline Sandstone adjacent to the study area in Gale Hills. The speculative silica sand resources in the study area are contained in the Aztec and Baseline Sandstones. Although tonnages are estimated to be large, samples indicate the sandstone is somewhat less pure than that currently being mined.

\section{MINERAL RESOURCE POTENTIAL}

The Muddy Mountains WSA has a high potential for borate minerals, lithium, and the clays associated with them, a moderate to high potential for zeolite minerals, and possibly some oil and gas potential. There is apparently little potential for metals other than lithium.

\section{Mineral Potential}

Borate minerals are confined to the lower part of the Lovell Wash Member and in some places to the uppermost beds of the Bitter Ridge Limestone Member of the Horse Spring Formation. This part of the stratigraphic section is exposed within the boundary of the WSA in the southern and western parts of White Basin and in the Lovell Wash area (fig. 4). It also occurs within the WSA in the shallow subsurface of western
White Basin beneath the red sandstone unit. Although nearly all of the production of borate minerals took place just outside, or right on, the WSA boundary, any exposure of the Lovell Wash or uppermost Bitter Ridge Limestone Members is considered herein as a potential source for calcium borate minerals. Apparently, the chief controlling factor that localized mineralization was syndepositional spring activity (Bohannon, 1982a). Ancient centers of spring activity are common in this part of the stratigraphic section, and there is a high potential for undiscovered centers of mineralization within the WSA, especially in the subsurface of western White Basin. Thus, the outcrops of the Lovell Wash and uppermost Bitter Ridge Limestone Members are shown as high borate potential areas on figure 4 . The results of boron analyses from stream-sediment samples failed to indicate the presence of any previously undiscovered borate resources within the WSA. However, stream-sediment sampling techniques (Bohannon and Vine, 1982) do not work well for boron unless it is present in heavy, insoluble minerals such as tourmaline. Colemanite deposits, such as those in and near the WSA, are generally not detectable by this technique.

Borate resources at the Anniversary Mine are an estimated 380,000 tons $(345,000$ t) of low-grade reserves and about $2,000,000$ tons $(1,800,000 \mathrm{t})$ of inferred reserves averaging $15-20$ percent $\mathrm{B}_{2} \mathrm{O}_{3}$. Because underground workings were inaccessible, data are insufficient to make estimates for the American Borax Mine in White Basin.

Reconnaissance sampling and analysis for lithium within the Horse Spring Formation in the Muddy Mountains area (Bohannon and Meier, 1976; BrennerTourtelot and Glanzman, 1978; and Brenner-Tourtelot, 1979) and similar detailed sampling of the Lovell Wash and uppermost Bitter Ridge Limestone Members of that formation in the WSA by the U.S. Geological Survey (Bohannon and Vine, 1982) and the U.S. Bureau of Mines indicate that the Lovell Wash and upper Bitter Ridge Limestone Members are highly enriched in lithium. The regional reconnaissance sampling indicates that other members of the Horse Spring Formation have only limited lithium enrichment in the vicinity of the WSA. Lithium content from 182 samples from the Lovell Wash and uppermost Bitter Ridge Limestone Members ranges from 78-2,040 ppm and, of these, only 4 samples have values below 200 ppm. Vine (1980, fig. 4, p. 64a) ranked potential lithium resources in rocks and sediments and suggested that any deposit having a thickness on the order of that of the Lovell Wash Member and average concentrations of 300-1,000 ppm lithium "warrants further search" for lithium resources. He further concluded that a deposit $30 \mathrm{ft}(9 \mathrm{~m})$ thick containing concentrations between 1,000 and $3,000 \mathrm{ppm}$ constitutes a "major resource potential." Because the detailed sampling program indicates that beds having lithium contents greater than 1,000 ppm are abundant in the Lovell Wash and uppermost Bitter Ridge Limestone Members, these units are considered herein as having major lithium resource potential, and they are shown so on figure 4 . As in the case of borate minerals, a similar potential for lithium minerals exists in the subsurface of western White Basin. The lithium values in the Lovell Wash and upper part of the Bitter Ridge Limestone Members are anomalously high compared with values reported from other similar deposits in 
other parts of the Basin and Range, and they are considerably higher than the background lithium values of the southern Nevada region (Bohannon and Meier, 1976). Techniques for the effective extraction of lithium from sediments and sedimentary rocks are not available to the lithium industry at present. Nonetheless, future demands on the lithium industry may warrant consideration of the Lovell Wash and uppermost Bitter Ridge Limestone Members within the WSA as targets for lithium exploration and possible production someday.

Zeolite minerals occur in mint-green-colored airfall and reworked airfall-tuff beds in the Rainbow Gardens and Thumb Members of the Horse Spring Formation. These beds average about $3 \mathrm{ft}(1 \mathrm{~m})$ in thickness; the thickest are $60 \mathrm{ft}(18 \mathrm{~m})$ and the thinnest 10 in. $(0.25 \mathrm{~m})$. The greatest lateral extent of these beds is generally not more than about $1,000 \mathrm{ft}$ $(300 \mathrm{~m})$, and most do not extend farther than about 400 ft $(120 \mathrm{~m})$ laterally. The limited lateral extent is chiefly due to faulting. The locations of the thickest and most abundant zeolitic tuff beds are shown on figure 4.

Zeolite resources in the Gale Hills, Lovell Wash, and Bitter Spring Valley areas (8 localities) are about 4.7 million tons ( 4.3 million $t$ ) of inferred resources averaging 84 percent clinoptilolite with a cation exchange capacity of 1.6 milliequivalents per gram (meq/g). Zeolite resources were calculated based on samples from tuff beds that range from $1 \mathrm{ft}(0.3 \mathrm{~m})$ to $60 \mathrm{ft}(18 \mathrm{~m})$ thick and contain at least 75 percent zeolite minerals. Zeolite minerals have not been mined in the study area, but sampling confirmed that Horse Spring Formation tuff beds in the study area are locally zeolite bearing. Technological advances have increased the number of uses for zeolite minerals as well as the demand (Sand and Mumpton, 1978). The zeolite-bearing tuff beds range from 1 to $60 \mathrm{ft}(0.3$ to $18 \mathrm{~m}$ ) thick and dip from $10^{\circ}$ to $40^{\circ}$. The tuffs are interbedded with sandstone, siltstone, limestone, and claystone of the Thumb and Rainbow Gardens Members of the Horse Spring Formation. The zeolite minerals apparently formed in a saline-alkaline lake environment, a closed hydrologic system. Predominant zeolite is clinoptilolite, which occurred in 64 of 119 samples. Cation exchange capacity $\left(\mathrm{NH}_{4}\right.$ absorption) for 25 of the samples was between 0.70 and $2.1 \mathrm{meq} / \mathrm{g}$.

Radioactive mineral occurrences in and near the WSA have no apparent economic potential. The potential for undiscovered deposits of radioactive minerals was not investigated in detail for this study.

Building stone is shown with low potential on figure 4. It has been mined, and the immediate vicinity of the mine should be regarded as having high potential.

In the light of the stream-sediment sampling results, the Muddy Mountains WSA appears to offer little potential for surface exposures of the studied metallic minerals. However, because subsurface exploration was not attempted and geophysical exploration was not employed in the study, a definitive statement regarding subsurface potential of the area cannot be made.

The WSA is in a geologic terrane similar to the nearby terrane at the Goodsprings district where lead, zinc, copper, gold, silver, and uranium have been mined (Hewett, 1931). However, the Goodsprings mineral deposits are closely associated with inter- mediate to silicic plutonism and volcanism which is absent in the WSA. Basalt and basaltic andesite flows and intrusions occur immediately south of the WSA, but are apparently not associated with metallic mineralization. Widespread intermediate volcanic and intrusive rocks are present a few miles southeast of the WSA (Anderson, 1973), although these are not mineralized. Because of the lack of volcanic and exposed intrusive rocks in the WSA, it is herein considered unlikely that large subsurface metallic mineral deposits exist within its boundaries.

\section{Oil and Gas Potential}

The Muddy Mountains WSA is located at the eastern margin of the Cordilleran overthrust belt, a linear zone of thrust faults and other compressional features of late Mesozoic and early Tertiary age that passes through Utah, Wyoming, Idaho, and Mont ana and stretches from north of the Canadian border at least to southern Nevada. Because oil and gas are produced from this belt in other states, notably in northern Utah and Wyoming, the part of the belt in southern Nevada is considered an area of high petroleum resource potential by the petroleum industry as well (Petroleum Information Corporation, 1981). In the producing parts of the overthrust belt, reservoir rocks, abundant structural and stratigraphic traps, and source rocks all occur. In southern Nevada, on the other hand, it has not been demonstrated that all these necessary features are present.

Five exploratory oil and gas test holes have been drilled in the vicinity of the WSA. Two of these, the Rosen Oil Corporation \#1 Muddy Dome well (total depth 5,666 ft) and the Shell Oil Corporation \#1 Bowl of Fire well (total depth 5,919 ft), were drilled within $1,000 \mathrm{ft}(300 \mathrm{~m})$ and $1 \mathrm{mi}(1.6 \mathrm{~km})$, respectively, of the southern boundary of the WSA (fig. 1). The United Petroleum Corporation \#1 Apex Wildcat well (total depth 1,281 ft) and the Southern Nevada Oil Corporation \#1 Apex Wildcat well (total depth 1,455 ft) were both drilled about $6 \mathrm{mi}(10 \mathrm{~km})$ from the western boundary of the WSA near Interstate 15 (fig. 1). The Mobil Oil \#1A Virgin River well (total depth 19,562 ft), which was drilled in the southern part of the Virgin River Valley (fig. 1), represents the most ambitious attempt at local oil and gas exploration. None of the drill holes produced oil or gas, and none penetrated thrust faults of the overthrust belt. The Muddy Dome and Bowl of Fire holes were spudded in rocks inferred to be autochthonous; the Virgin River hole was spudded in Tertiary rocks and drilled through the autochthon at depth; and the two Apex holes were spudded in allochthonous rocks, but were not deep enough to penetrate any thrusts.

Because the structures and tectonic features associated with the overthrust belt affected only earliest Tertiary and older rocks, the local Tertiary stratigraphic section within the WSA has not been targeted by the petroleum industry for oil exploration (elsewhere in Nevada, however, petroleum is being produced from Tertiary beds; Paleozoic rocks are the source of that petroleum). Also, these local Tertiary rocks were deposited in closed, evaporitic basins, and they contain little or no organic matter; as such their lithologies are not favorable for oil and gas production. Tertiary rocks are exposed at the surface throughout much of the WSA, and they conceal older 
rocks and structures. Because of the extent and thickness of concealing cover and the complexity and intensity of Tertiary structural effects, the favorableness of petroleum potential in rocks buried beneath the Tertiary beds of the WSA is not known. However, interpretative cross sections drawn through White Basin, Bitter Spring Valley, and the Bowl of Fire (Bohannon, 1982b) predict a high degree of structural complexity with closely spaced, young faults cutting the older rocks. No buried Mesozoic petroleum traps that have remained undisturbed by Tertiary faulting are thought to lie preserved beneath the Tertiary rocks of the WSA. Thus, the petroleum potential of the eastern, southern, and southwestern parts of the WSA, where Tertiary rocks and structures are widespread, is considered herein to be low.

The Mesozoic and early Tertiary(?) Muddy Mountain thrust of the overthrust belt is exposed in the Muddy Peak-Buffington Pockets area in the northcentral part of the WSA. The thrust is exposed in a broad, gentle arch that is closed on its south end and is cut by numerous Tertiary faults. The autochthonous Mesozoic rocks in the core of the arch beneath the thrust offer good potential as reservoir rocks, but local source rocks and a viable structural or stratigraphic trap might not be present. Local Paleozoic and Mesozoic rocks do not offer good potential as source rocks because clastic rocks of that age are red beds, and they lack organic-rich black shales. In addition, Harris and others (1980) showed high conodont color alteration indices for many of the Paleozoic rocks of the region indicating that they have been subject to high temperatures for long periods of time and that they are probably over mature with respect to the production of either oil or gas. In east-central Nevada, the Mississippian Chainman Shale was the source for petroleum that is produced in that area, but the Chainman is not present in the WSA, and the nearest known exposure of it is about $50 \mathrm{mi}$ to the north. The Muddy Mountain thrust surface does not provide a structural trap for petroleum within the north-central part of the WSA because it is eroded in the core of the arch and on the flanks it dips uniformly away from the core. Stratigraphic traps may exist in the autochthonous rocks beneath the thrust, and if those rocks are also affected by the arching, petroleum could be trapped in the crestal region of the arch. However, abrupt lateral facies changes, like those that produce stratigraphic traps, are not common in the rocks beneath the thrust, and the arching may simply be the result of the original shape of the thrust surface and it may not affect the subthrust rocks. Mapping by Bohannon (1982b) suggested that this interpretation is likely, but some petroleum industry spokesmen think that all the rocks are arched. As such, the petroleum potential of the WSA is incompletely understood, but it is herein regarded as poor chiefly because of the lack of known potential source rocks.

\section{REFERENCES CTIED}

Anderson, R. E., 1973, Large magnitude late Tertiary strike-slip faulting north of Lake Mead, Nevada: U.S. Geological Survey Professional Paper 794, 18 p.
Bohannon, R. G., 1982 a, Nonmarine sedimentary rocks of Tertiary age in the Lake Mead region, southeastern Nevada and northwestern Arizona: U.S. Geological Survey Professional Paper 1259, in press.

1982b, Geologic map, tectonic map, and structure sections of the Muddy and northern Black Mountains, Clark County, Nevada: U.S. Geological Survey Miscellaneous Investigations Series Map I-1406, scale 1:62,500, in press.

1982 c, Geologic map of the Muddy Mountains Wilderness Study Area, Clark County, Nevada: U.S. Geological Survey Miscellaneous Field Studies Map MF-1458-A, scale 1:62,500.

Bohannon, R. G., and Bachhuber, Fred, 1979, Road log from Las Vegas to Keystone thrust area and Valley of Fire via Frenchman Mountain, in Newman, G. W., and Goode, H. D., eds., Basin and Range symposium and Great Basin field conference: Denver, Rocky Mountain Association of Geologists Guidebook, 1979, p. 579-596.

Bohannon, R. G., and Meier, A. L., 1976, Lithium in sediments and rocks in Nevada: U.S. Geological Survey Open-File Report 76-567, 17 p.

Bohannon, R. G., and Vine, J. D., 1982, Geochemical map of the Muddy Mountains Wilderness Study Area, Clark County, Nevada: U.S. Geological Survey Miscellaneous Field Studies Map MF1458-B, scale $1: 62,500$.

Brenner-Tourtelot, E. F., 1979, Geologic map of the lithium-bearing rocks in parts of the Frenchman Mountain and Henderson quadrangles, Clark County, Nevada: U.S. Geological Survey Miscellaneous Field Studies Map MF-1079, scale $1: 24,000,1$ sheet.

Brenner-Tourtelot, E. F., and Glanzman, R. K., 1978, Lithium-bearing rocks of the Horse Spring Formation, Clark County, Nevada: Energy (Pergamon Press), v. 3, no. 3, p. 255-262.

Harris, A. G., Wardlaw, B. R., Rust, C. C., and Merrill, G. K., 1980, Maps for assessing thermal maturity (conodont color alteration index maps) in Ordovician through Triassic rocks in Nevada and Utah and adjacent parts of Idaho and California: U.S. Geological Survey Miscellaneous Investigations Series Map I-1249, scale $1: 2,500,000,2$ sheets.

Hewett, D. F., 1931, Geology and ore deposits of the Goodsprings quadrangle, Nevada: U.S. Geological Survey Professional Paper 162, 172 p.

Petroleum Information Corporation, 1981, The overthrust belt, 1981: Denver, Colo.,Petroleum Information Corporation, $251 \mathrm{p}$.

Sand, L. B., and Mumpton, F. A., eds., 1978, Natural zeolites; occurrence, properties, use: New York, Pergamon Press, 546 p.

Smith, M. C., 1959, Mining and processing silica sands at Overton, Nevada, by Simplot Silica Products, Inc: U.S. Bureau of Mines Information Circular $7897,12 \mathrm{p}$.

Vine, J. D., 1980, Where on earth is all the lithium?, with a section on Uranium isotope studies, Fish Lake Valley, Nevada, by J. R. Dooley, Jr.: U.S. Geological Survey Open-File Report 80-1234, $114 \mathrm{p}$. 
Table 1.- Mines and prospects in the Muddy Mountains Wilderness Study Area and vicinity

\begin{tabular}{|c|c|c|c|}
\hline $\begin{array}{l}\text { Map } \\
\text { No. }\end{array}$ & Name & Workings & Resource data \\
\hline 1 & Vanderbilt Mine & $\begin{array}{l}\text { Open pit and several } \\
\text { bulldozer cuts. }\end{array}$ & $\begin{array}{l}\text { Limestone with clay interbed. One sample, } \\
\text { high-quality montmorillonite. Several } \\
\text { thousand tons mined. About } 500 \text { tons } \\
(450 \text { t) stockpiled, and resources for } \\
\text { several years exist. }\end{array}$ \\
\hline 2 & Unnamed prospect & Trench ....... & $\begin{array}{l}\text { Fanglomerate-sandstone. One sample, no other } \\
\text { anomalies. }\end{array}$ \\
\hline 3 & Colorock Quarry & $\begin{array}{l}\text { Several small } \\
\text { quarry sites. }\end{array}$ & $\begin{array}{l}\text { Sandstone with iron staining along fractures; } \\
\text { samples considered suitable for building- stone } \\
\text { uses. Several hundred tons of sandstone have } \\
\text { been quarried, and unlimited resources remain. }\end{array}$ \\
\hline 4 & Unnamed prospect & Pit. ....... & $\begin{array}{l}\text { Iron-stained sandstone for local use as building } \\
\text { stone. No other anomalies. }\end{array}$ \\
\hline 5 & Unnamed prospect & Pit. ....... & $\begin{array}{l}\text { Limestone with tufa deposits. One sample } \\
\text { contained } 20 \text { percent clinoptilolite and } 300 \mathrm{ppm} \\
\text { lithium; no other anomalies. }\end{array}$ \\
\hline 6,7 & Lucky Strike Group & $\begin{array}{l}5 \text { trenches, } 4 \text { bull- } \\
\text { dozer cuts. }\end{array}$ & $\begin{array}{l}\text { Tuffaceous sandstone with clay interbeds, } 7 \\
\text { samples. One sample contained } 800 \mathrm{ppm} \\
\text { lithium. No other anomalies. }\end{array}$ \\
\hline 8 & Unnamed prospect & Pit. ........ & $\begin{array}{l}\text { Tuffaceous sandstone with silt interbeds. One } \\
\text { sample contained } 300 \mathrm{ppm} \text { lithium but no other } \\
\text { anomalies. }\end{array}$ \\
\hline 9 & Unnamed prospect & Pit......... & $\begin{array}{l}\text { Tuffaceous sandstone with silt and clay } \\
\text { interbeds. One sample contained } 35 \text { percent } \\
\text { clinoptilolite; no other anomalies. }\end{array}$ \\
\hline 10 & Patches Group. ... & Trench ....... & $\begin{array}{l}\text { Tuffaceous, sandy limestone with clay interbeds. } \\
\text { One sample, no anomalies. }\end{array}$ \\
\hline 11 & Unnamed prospect . . & Trench ........ & $\begin{array}{l}\text { Green to pink volcanic ash. One sample contained } \\
300 \mathrm{ppm} \text { lithium. No other anomalies. }\end{array}$ \\
\hline $12-15$ & American Borax Mine & $\begin{array}{l}\text { Numerous small pits } \\
\text { and adits; several } \\
\text { long adits now caved } \\
\text { and inaccessible. }\end{array}$ & $\begin{array}{l}\text { Claystone, limestone, and tuff with borate } \\
\text { interbeds. Nine samples contained as much } \\
\text { as } 840 \mathrm{ppm} \text { lithium and } 10.7 \text { percent boron. } \\
\text { Several thousand tons have been mined and } \\
\text { an unestimated resource remains. See text. }\end{array}$ \\
\hline 16 & Unnamed prospect .. & $\begin{array}{l}\text { 65-ft }(20 \mathrm{~m}) \text { adit } \\
\text { with } 60 \text {-ft } \\
(18 \mathrm{~m}) \text { crosscut. }\end{array}$ & $\begin{array}{l}\text { Sandy clay with tuffaceous interbeds. One } \\
\text { sample contained } 40 \text { percent clinoptilolite. } \\
\text { No other anomalies. }\end{array}$ \\
\hline 17 & DWB Group. . . . . & $\begin{array}{l}3 \text { trenches, } 1 \text { shaft, } \\
50-\mathrm{ft}(15 \mathrm{~m}) \text { adit. }\end{array}$ & $\begin{array}{l}\text { Sandy clay with tuffaceous interbeds } \\
\text { (colemanite nodules in clay matrix). One } \\
\text { sample contained } 13 \text { percent boron. No other } \\
\text { anomalies. Five tons ( } 4.5 \mathrm{t} \text { ) of colemanite } \\
\text { nodules stockpiled on dump. }\end{array}$ \\
\hline 18 & Unnamed prospect & 43-ft $(13 \mathrm{~m})$ adit. .. & $\begin{array}{l}\text { Thin-bedded sandy limestone. One sample } \\
\text { contained } 400 \mathrm{ppm} \text { lithium. No other anomalies. }\end{array}$ \\
\hline
\end{tabular}


Table 1.-Mines and prospects in the Muddy Mountains Wilderness Study Area and vicinity-Continued

\begin{tabular}{ccc}
\hline $\begin{array}{l}\text { Map } \\
\text { No. }\end{array}$ & Name & Workings \\
\hline 19 & North Contact & $\begin{array}{c}\text { Two } 8-\mathrm{ft}(2.5 \mathrm{~m}) \\
\text { adits. }\end{array}$ \\
& & \\
& & \\
& DWG. ...... & $\begin{array}{c}\text { Trench, 26-ft }(8 \mathrm{~m}) \\
\text { shaft, 16-ft } \\
(5 \mathrm{~m}) \text { and } 48-\mathrm{ft} \\
(14.5 \mathrm{~m}) \text { adits. }\end{array}$ \\
\end{tabular}

$21,23 \quad$ EABAEX Group .... 6 trenches......

22 Unnamed prospect
31-ft $(9.4 \mathrm{~m})$ adit with $35-\mathrm{ft}(11 \mathrm{~m})$ crosscut.

Unnamed prospect

4 adits, 1 12-ft $(3.5 \mathrm{~m})$, the others caved.

Unnamed prospect

4 adits, 45, 40, 29, $15 \mathrm{ft}(13.5,12$, 9 , and $4.5 \mathrm{~m}$ ).

Moby Dick Group 3/8-in. diameter drill holes.

Several short adits, main adit with more than 7,000 ft $(2,100 \mathrm{~m})$ of underground workings on 5 levels.

Trench .......

3 adits, 19, 56, 78 ft $(6,17$, $24 \mathrm{~m})$.
Resource data

Siltstone with clay interbeds. Two samples contained 400 and $1,000 \mathrm{ppm}$ lithium, and a select sample of colemanite nodules in clay matrix contained 13.6 percent boron. No other anomalies were determined. One ton of colemanite nodules stockpiled on ciump.

Fanglomerate with clay interbeds. One sample, $500 \mathrm{ppm}$ lithium. No other anomalies.

Sandy clay with silt interbeds. Colemanite nodules in clay matrix. Two select samples of nodules contained 14.2 and 12.6 percent boron. No other anomalies. Twelve tons $(10.9 \mathrm{t})$ of colemanite nodules stockpiled on dumps.

Sandy clay with silt interbeds. One sample, no anomalies.

Silty sandstone. One sample contained 800 ppm lithium. No other anomalies.

Gray tuff. One sample contained 800 ppm lithium. No other anomalies.

Calcite-gypsum interbedded with siltstone. Three samples, no anomalies.

Conglomerate. One sample, no anomalies.

Limestone with tuff interbeds. One sample contained $500 \mathrm{ppm}$ lithium. No other anomalies.

Claystone, siltstone, limestone, and tufa with borate interbeds. 37 samples contained as much as $1,000 \mathrm{ppm}$ lithium and 12.4 percent boron. 200,000 tons $(180,000 \mathrm{t})$ mined and 380,000 tons $(345,000 \mathrm{t})$ of marginal reserves. $2,000,000$ tons $(1,800,000 t)$ of inferred resources. See text.

Volcanic ash bed. One sample contained 95 percent clinoptilolite. No other anomalies.

Volcanic ash, 6 samples. Two samples contained 95 and 100 percent clinoptilolite. No other anomalies. 


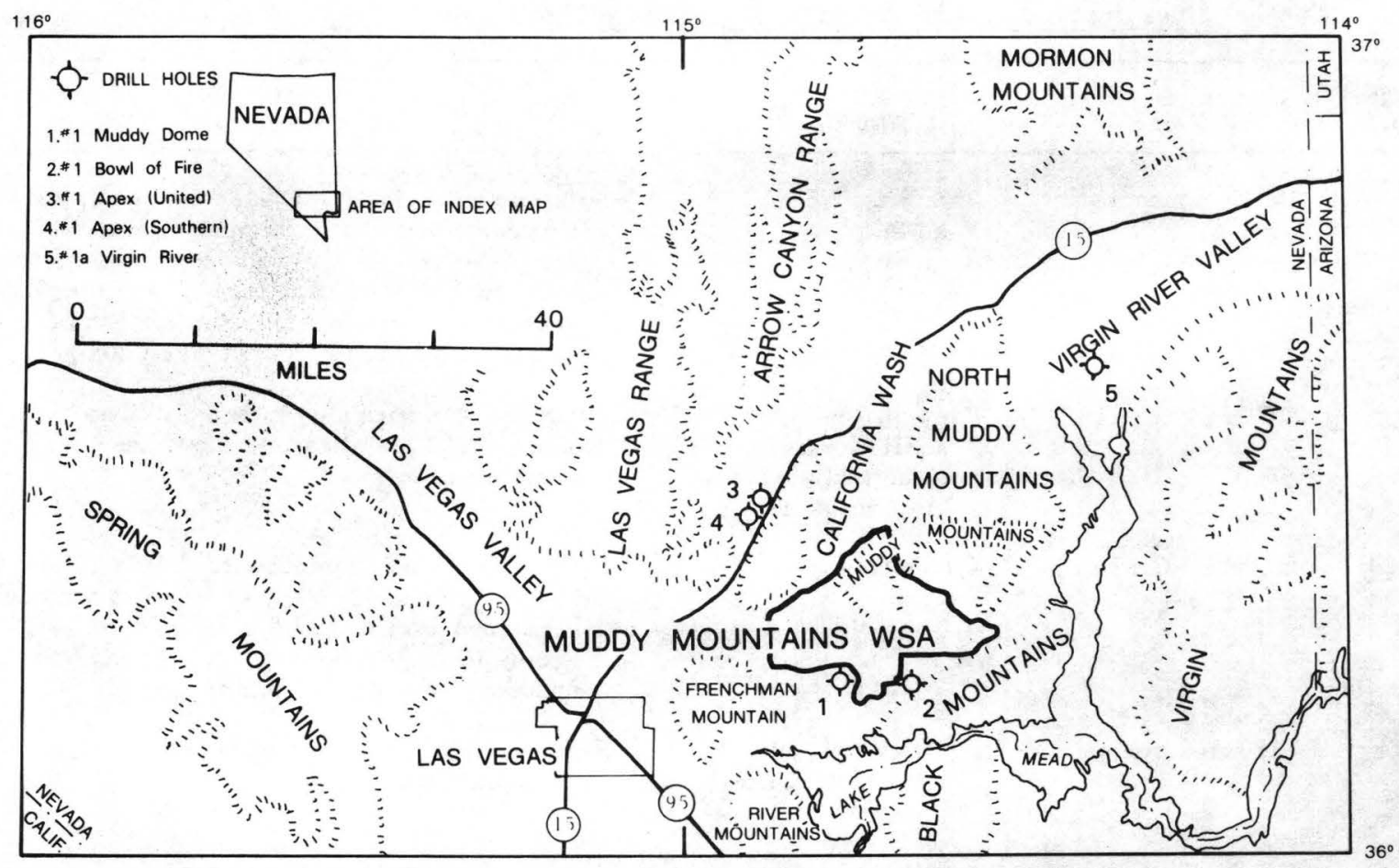

FIGURE 1. -- Index map showing the location of the Muddy Mountains Wilderness Study Area, the locations of five oil and gas test holes, and major geographic features. 


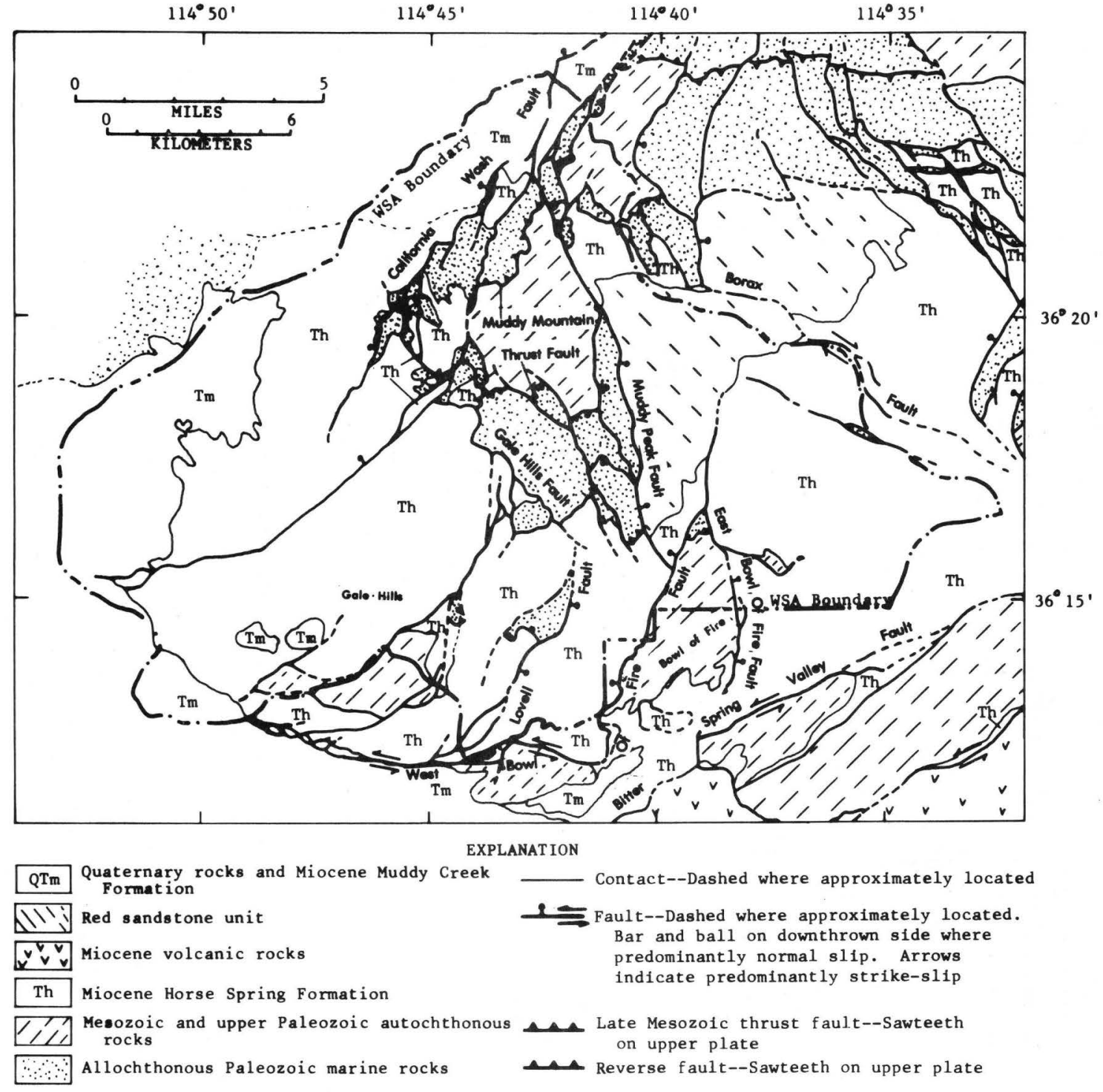

FIGURE 2. -- Simplified geologic map showing the locations of major faults. 
$x$ MINES AND PROSPECTS

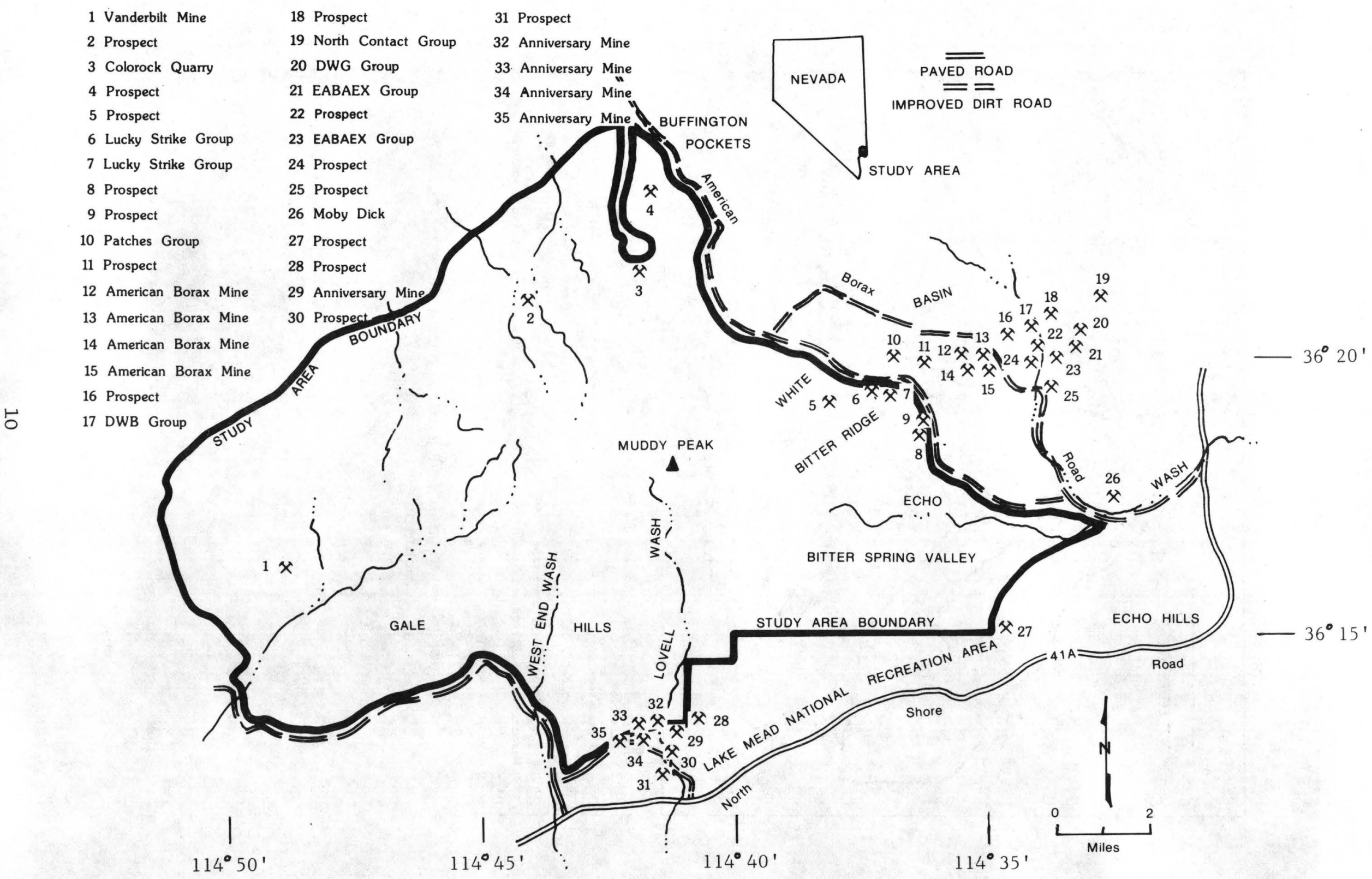

FIGURE 3. -- Locations and names of mines and prospects in the Muddy Mountains Wilderness Study Area. 


\section{EXPLANATION}

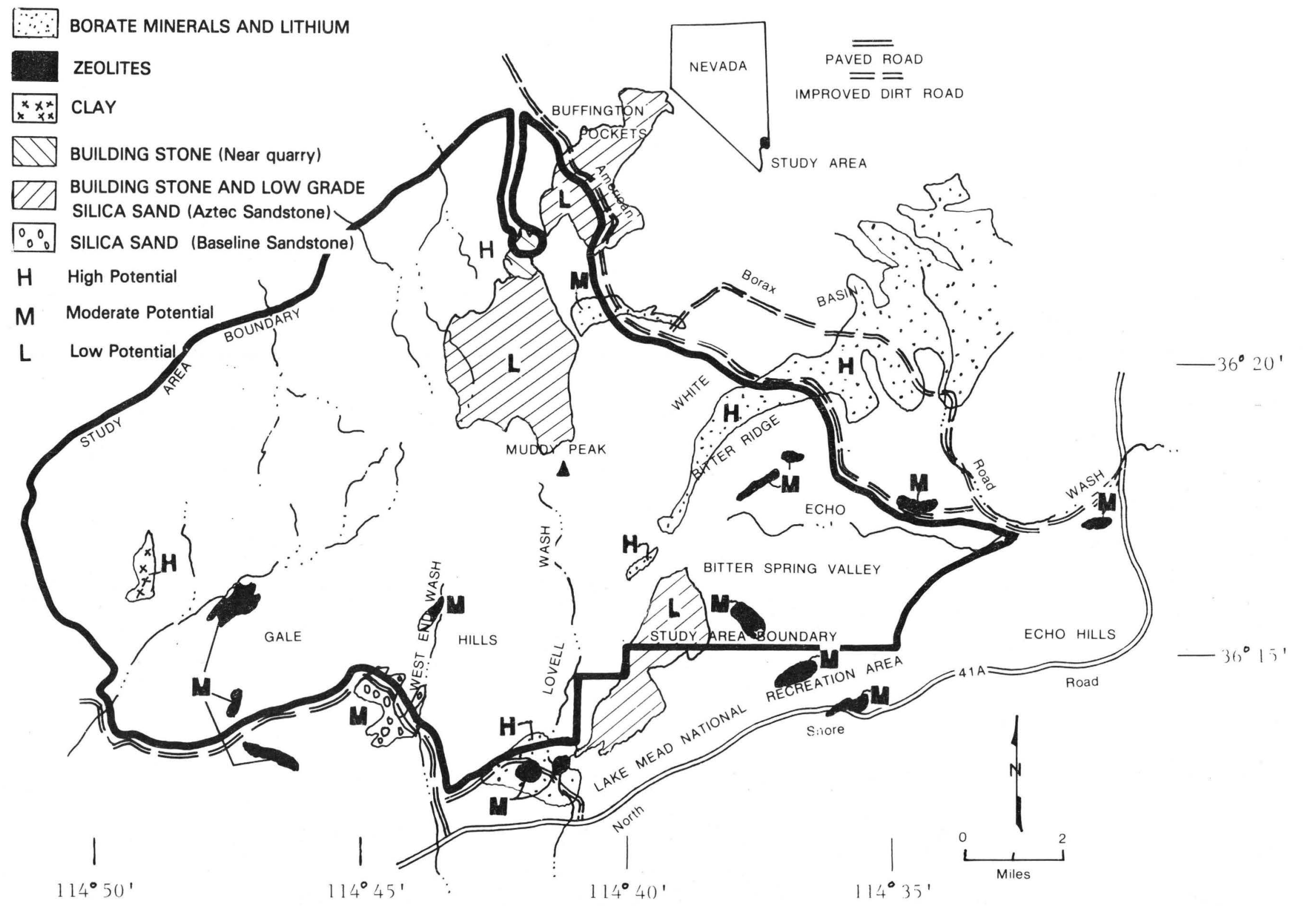

FIGURE 4. -- Mineral potential map of the Muddy Mountains Wilderness Study Area showing various types of minerals and commodities present and the relative potential of each. 